4. Ghassemian M., Nowzari H., Lajolo $C_{.}$, Verdugo F., Pirronti T., et al. (2012), "Thethickness of facial alveolar bone overlying healthy maxillary anterior teeth", Periodontol,83(2), pp.187-197.

5. Januario A. L., Barriviera M., Duarte W. R. (2008), "Soft tissue cone-beam computed tomography: a novel method for the measurement of gingival tissue and the dimensions of the dentogingival unit", J Esthet Restor Dent, 20(6), pp.366-373.

6. Zekry A., Wang R., Chau A. C., Lang N.P.
(2012), "Facial alveolar bone wall width -a conebeam computed tomography study in Asians", Clin Oral Implants Res, 25(2),pp.194-206.

7. Grunder U., Gracis S., Capelli M. (2005), "Influence of the 3-D bone-to- implant relationship on esthetics", Int J Periodontics Restorative Dent, 25(2), pp.113-119.

8. Mandelaris G. A., Vence B. S., Rosenfeld A. L., Forbes D. P. (2013), "A classificationsystem for crestal and radicular dentoalveolar bone phenotypes", Int ] PeriodonticsRestorative Dent, 33(3), pp.289-296.

\title{
KẾT QUẢ PHÂN TÍCH DƯớI NHÓM HÓA TRI VINORELBIN METRONOMIC UNG THƯ PHỔI KHÔNG TẾ BÀO NHỎ GIAI ĐOẠN TIẾN XA
}

\section{TÓM TẮT}

Mục tiêu: Nghiên cứu nhằm đánh giá các yếu tố liên quan đến kết quả điều trị Vinorelbine Metronomic ung thư phổi không tế bào nhỏ giai đoan tiến xa. Đối tướng và phương pháp: Ung thư phổi không tế bào nhỏ tiến triển sau điều trị hóa chất bước 1 . Nghiên cứu hồi cứu. Điều tri: Vinorelbine uống mối lần $50 \mathrm{mg}$, tuần $2-3$ lần tùy thể trạng bệnh nhân và quyết định của thày thuốc Kết quả và kết luân: Kết quả điêu trị không khác biệt giữa các nhóm tuổi. Kết quả cao hơn ở những bênh nhân điều trị bước 2 so với điều trị từ bước 3; ECOG 0,1 so với ECOG >1.

Tư khóa: Vinorelbine metronomic, giai đoạn tiến xa, ung thư phổi không tế bào nhỏ

\section{SUMMARY}

RESULTS OF ANALYSIS SUBGROUPS OF NON-SMALL CELL LUNG CANCER TREATED WITH VINORELBINE METRONOMIC

Objective: To evaluate treatment result of subgroups of Advanced - stage Non - small cell Lung cancer treated by Vinorelbine Metronomic. Patients: Advanced - stage Non - small cell Lung cancer patients progressed after first - line chemotherapy. Method: Retrospective study. Patients were given Vinorelbine $50 \mathrm{mg}$ twice or 3 times a week. Results and Conclusion: Treatment results did not differ between age groups. Results were higher in patients on second - line treatment compared with treatment from third line; ECOG 0,1 vs ECOG > 1 .

Keywords: Vinorelbine metronomic, advanced stage, non - small cell lung cancer

\section{I. ĐĂT VẤN ĐỀ}

Điều tri ung thư phổi không tế bào nhỏ (UTPKTBN) giai đoạn tiến xa nhằm mục đích kéo

*Bệnh viện K trung ương

Chịu trách nhiệm chính: Nguyễn Thị Thái Hòa

Email: Bshoabvk@gmail.com

Ngày nhân bài: 10/2/2021

Ngày phản biên khoa hoc: 11/3/2021

Ngày duyệt bài: 25/3/2021
Nguyễn Thị Thái Hòa*

dài sống còn, giảm triệu chứng, nâng cao chất lượng sống cho người bệnh. Đây là một nhóm bệnh nhân có tiên lượng rất dè dặt với điều trị chủ đạo là các điều trị nội khoa ung thư kết hợp với chăm sóc giảm nhe. Với những hiểu biết gần đây về con đường dẫn truyền tín hiệu tế bào cũng như các chốt kiểm soát miễn dịch, nhiều thế hê thuốc đích và miễn dich đã đem lại hiêu quả cho nhiều người bệnh. Tuy nhiên, tại Việt nam phần lớn các bênh nhân vẫn điêu trị hóa chất từ bước 1 đến các bước sau. Khi đã thất bai với điều trị bước 1 , thể trang bênh nhân thường yếu, điêu trị phác đồ bộ đôi không còn thích hợp vì ít cải thiên hiêu quả và đôc tính cao. Hóa trị metronomic là môt cách thức điều trị khác biêt so với điều trị cổ điển, bởi được đưa vào cơ thể bởi các liêu nhỏ, liên tục. Ngoài tác dụng kháng u theo cơ chế như các hóa tri khác, điều trị metronomic còn có tác dụng chống tăng sinh mạch máu và thay đổi vi môi trường miễn dịch; từ đó nâng hiêu quả của điều trị với đôc tính tối thiểu $[1,2]$. Các nghiên cứu trên thế giới đã cho thây những kết quả đáng khích lệ của Vinorelbine Metronomic đối với UTPKTBN giai đoan tiến xa $[3,4]$. Nhằm có những phân tích sâu hơn về kết quả của điều trị này trên những nhóm bệnh nhân khác nhau, chúng tôi tiến hành đề tài này nhằm mục tiêu: "Đánh giá kết quả điều trị Vinorelbine metronomic đối với ung thư phổi không tế bào nhỏ giai đoạn tiến xa trên các phân nhóm bệnh nhân".

\section{II. ĐỐI TƯƠNG VÀ PHƯƠNG PHÁP NGHIÊN CỨU \\ 2.1. Đối tượng nghiên cứu}

Tiêu chuẩn chọn: Bệnh nhân được chẩn đoán là ung thư phổi không tế bào nhỏ giai đoạn IV, điều trị từ bước 2 bằng vinorelbine metronomic tại Bênh viên $K$ từ $1 / 2019$ đến 6/2020

Tiêu chuẩn loại: Di căn não 
2.2. Phương pháp nghiên cứu: Nghiên cứu hồi cứu, mô tả cắt ngang có theo dõi dọc

Phác đồ sử dụng trong nghiên cứu: Vinorelbine uống mối lần $50 \mathrm{mg}$, tuần 2 -3 lần tùy thể trạng bệnh nhân và quyết định của thày thuốc

\section{Chỉ tiêu nghiên cứu:}

- Phân tích những yếu tố liên quan đến thời gian có điều trị (có lợi ích lâm sàng) bao gồm: Tuổi, số bước điều tri

- Thời gian điều trị: từ lúc bắt đầu đến lúc kết thúc điêu trị do bệnh tiến triển hoặc không dung nạp được, hoặc tử vong do bất kỳ nguyên nhân gì.

Chon mấu: Thuân tiện

Xử lý số liệu: Sử dung phần mềm SPSS 16.0

III. KẾT QUẢ NGHIÊN CỨU

3.1. Một số đặc điểm bệnh nhân

Bảng 3.1. Đặc điểm bệnh nhân

\begin{tabular}{|c|c|c|c|}
\hline \multicolumn{2}{|c|}{ Đặc điếm } & $\mathbf{N}$ & $\mathbf{\%}$ \\
\hline \multirow{2}{*}{ Tuổi } & $<60$ & 11 & 47,8 \\
\cline { 2 - 4 } & $\geq 60$ & 12 & 52,2 \\
\hline \multirow{2}{*}{ ECOG } & 0,1 & 16 & 69,6 \\
\cline { 2 - 4 } & 2,3 & 7 & 30,4 \\
\hline $\begin{array}{c}\text { Bước điều } \\
\text { trị }\end{array}$ & Bước 2 & 11 & 47,8 \\
\cline { 2 - 4 } & Sau bước 2 & 12 & 52,2 \\
\hline
\end{tabular}

Nhân xét: Tuối trung bình 60,5 (33-81). Nam/nữ: 16/7

3.2. Phân tích kết quả điêu trị theo các dưới nhóm

\subsubsection{Phân tích theo chỉ số toàn trạng}

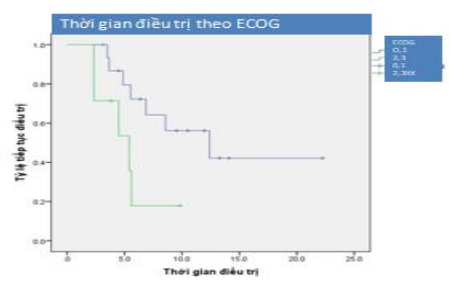

Biểu đố 3.1. Thời gian điều trị theo chỉ số toàn trạng Nhân xét: Chỉ số toàn trạng 0,1 và $>1$ có thời gian điều trị là 12,4 tháng, 5,4 tháng $(p=0,040)$

\subsubsection{Phân tích theo nhóm tuổi}

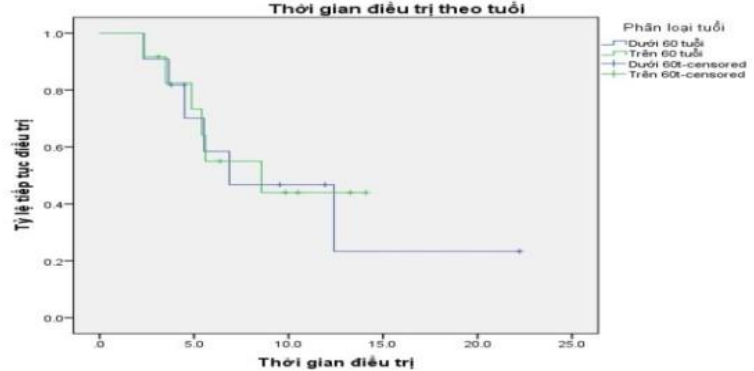

Biểu đồ 3.2. Thời gian điều trị theo nhóm tuôi
Nhận xét: Thời gian điều trị nhóm tuổi trên 60 và dưới 60 lần lượt là 6,87 và 8,$57 ; p=0,8$

\subsection{Bước điêuu trị}

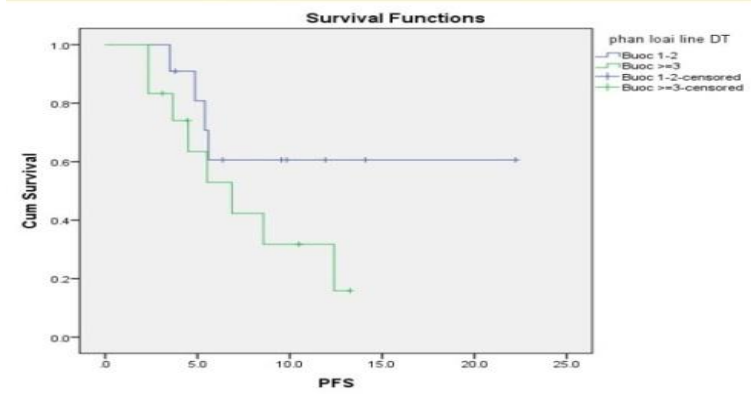

Biểu đồ 3.3. Thời gian điều trị theo số bước điều trị

Nhận xét: Thời gian điều trị cho bệnh nhân điều trị bước 2 chưa đạt trung vị, điều trị ngoài bước 2: 6,87 tháng $(p=0,15)$

\section{BÀN LUÂ̂N}

So với phương pháp kinh điển, hóa trị metronomic là điều trị liều thấp và khoảng nghỉ ngắn. Hiệu quả điều trị đạt được không chỉ bởi cơ chế kháng $u$ của thuốc, mà còn bởi ức chế tăng sinh mạch máu và thay đổi vi môi trường miễn dịch của khối u. Trong thử nghiệm lâm sàng pha II (MOVE trial), Vinorelbine uống đơn tri liêu được sử dung là lựa chọn bước 1 cho các bệnh nhân UTPKTBN giai đoạn tiến triển. Kết quả thu được tỷ lệ bệnh nhân đạt lợi ích lâm sàng là $58,1 \%$; sống thêm toàn bộ trung vị là 9 tháng, sống không tiến triển trung vị là 5 tháng, thuốc được dung nap tốt, ít độc tính [5]. Chính vì liều đưa vào mồi lần điều trị là thấp nên phương pháp này giảm thiểu tối đa độc tính của điều trị. Do dung nạp tốt, nên hóa trị metronomic rất thích hợp cho các đối tượng bệnh nhân cao tuổi, có bệnh lý phối hợp. Camerini (2010) sử dụng Vinorelbine uống đơn trị liệu cho 43 BN với tuổi TB 77 cũng mang lại kết quả khả quan với tỷ lệ kiểm soát bệnh đạt $48,8 \%$, trung vị sống thêm 8 tháng, thuốc có độ dung nạp tốt, mọi độc tính đều được ghi nhận ở mức độ nhe [6]. Trong nghiên cứu năm 2017 tai Thổ Nhĩ Kỳ, C.Bilir và cộng sự đánh giá lợi ích lâm sàng của hóa trị metronomic với vinorelbine trên nhóm bênh nhân UTPKTB tiến triển cao tuổi thể trang yếu mắc nhiều bênh phối hợp. Nghiên cứu bao gồm 35 bệnh nhân có tuổi trung bình là 76 (65 -86 tuổi), có các bệnh lý mạn tính phối hợp: bênh phổi tắc nghẽn mạn tính $(74 \%)$, đái tháo đường điều trị insuline $(20 \%)$, suy tim (29\%), can thiệp mạch vành (14\%). Tất cả các bệnh nhân được uống vinorelbine 30mg, 3 lần 
mỗi tuần (mỗi thứ 2, thứ 4 và thứ 6 ) cho đến khi bệnh tiến triển và nhiễm độc độ 4 . Kết quả nghiên cứu tỉ lệ bệnh ổn định là $43 \%$, bệnh tiến triển $31 \%$, thời gian sống thêm không tiến triển là 4 tháng (2- 15 tháng), và thời gian sống còn toàn bộ là 7 tháng (3-24 tháng). Không có trường hợp tử vong được ghi nhận do độc tính điều trị, chỉ có 1 bệnh nhân có độc tính độ 3 bị mệt mỏi và tiêu chảy phải nhập viện [3]. Trong nghiên cứu của chúng tôi $12 / 23$ bệnh nhân có tuổi trên 60 . Kết quả cho thây nhóm bệnh nhân trên 60 và dưới 60 tuổi có kết quả điều trị không khác biệt. Tuy nhiên, những bệnh nhân thể trạng tốt $(E C O G 0,1)$ có kết quả vượt trội so với nhóm bệnh nhân ECOG $>1$ (12,4 tháng so với 5,4 tháng; $p=0,04$ )

Điều tri bước 2 và sau bước 2 cũng đã được đánh giá bởi tác giả . mặc dù các khuyến cáo điều trị không thực hiện thường quy các điều trị sau bước 2 . Tuy nhiên thực hành lâm sàng vẫn điều trị nếu có triệu chứng và tùy từng đối tượng bệnh nhân. Trong nghiên cứu này, mặc dù $79,6 \%$ bệnh nhân điều trị sau bước 2 nhưng cũng đạt được tỷ lệ ổn định bệnh gần 20\% [7]. Nghiên cứu của chúng tôi có $12 / 23$ bệnh nhân điêu trị sau bước 2 . Kết quả cho thấy sống thêm không tiến triển lâm sàng của nhóm này chỉ đạt 6,87 tháng, thấp hơn so với điều trị bước 2 .

\section{KẾT LUÂ̂N}

- Trung vị thời gian kéo dài lợi ích lâm sàng ECOG 0,1 là 12,4 tháng

- Trung vị thời gian kéo dài lợi ích lâm sàng ECOG $>1$ là 5,4 tháng

- Trung vị thời gian kéo dài lợi ích lâm sàng trên 60 tuổi là 6,87 tháng

- Trung vị thời gian kéo dài lợi ích lâm sàng dưới 60 tuổi là 8,57 tháng

- Trung vị thời gian kéo dài lợi ích ở bệnh nhân điều trị bước 2: Chưa đạt

- Trung vị thời gian kéo dài lợi ích ở điều trị sau bước 2: 6,87 tháng

\section{TÀI LIẸU THAM KHẢO}

1. Antonio $G$, Nicola $S$, Antonnela $L$, et al. (2015) "Metronomic chemotherapy from rationale to clinical studies: a dream or reality". Clinical reviews in Oncology/ Hematology 95 (2015) 46-61.

2. Magdalena K-W, Maciej K. (2016) "Metronomic chemotherapy in non - small - cell lung cancer current status" Oncol Clin Pract 2016; 12, 2: 37-42.

3. C. Bilir ,S. Durak B, Kızılkaya, et al. (2017) "Efficacy of metronomic vinorelbine in elderly patients with advanced non-small-cell lung cancer and poor performance status". Curr Oncol. 2017 June;24(3):199-204.

4. MichelaD'Ascanio, Aldo Pezzuto, Chiara Fiorentino (2018), "Metronomic Chemotherapy with Vinorelbine Produces Clinical Benefit and Low Toxicity in Frail Elderly Patients Affected by Advanced Non-Small Cell Lung Cancer". Hindawi BioMed Research International Volume 2018 Article ID 6278403, 6 pages https:// doi.org/10.1155/2018/6278403.

5. Andrea Camerini, et al, (2015) " Metronomic oral vinorelbin as first -line treatment in elderly patients with advanced non - small cell lung cancer: result of a phase II trial (MOVE trial)". BMC Cancer 2015, 15-359.

6. Camerini , Valsuani, Mazzoni, Siclari, (2010) "Phase II trials of single- agent oral vinorelbine in elderly ( $\geq 70$ years) patients with advanced non small cell lung cancer and poor performance status". Ann Oncol (2010) 21(6): 1290-1295.

7. Emmanouil Kontopodis, Dora Hatzidak, Ioannis Varthalitis, et al (2013). "A phase II study of metronomic oral vinorelbine administered in the second line and beyond in non-small cell lung cancer (NSCLC): a phase II study of the Hellenic Oncology Research Group" Journal of Chemotherapy 2013 VOL. 25 NO. 1, 49- 55.

\section{TƯO'NG QUAN GIỮA ĐĂC ĐIÊM CARABELLI VÀ CHU VI THÂN RĂNG CỐI LỚN THỨ NHẤT VÀ THỨ HAI HÀM TRÊN TRONG ĐIỀU TRI NHA KHOA}

\section{Huỳnh Kim Khang ${ }^{1}$, Trương Châu Bửu Lộc ${ }^{1}$}

\section{TÓM TẮT}

Mục tiêu: Xác định mối tương quan giữa mức độ biểu hiện đặc điểm Carabelli và chu vi thân răng cổi

\footnotetext{
${ }^{1}$ Đại họ Y Dược TP.Hồ Chí Minh

Chịu trách nhiệm chính: Huỳnh Kim Khang

Email: kimkhanghuynh@yahoo.com

Ngày nhận bài: 2/2/2021

Ngày phản biện khoa hoc: 29/2/2021

Ngày duyệt bài: 21/3/2021
}

lớn thứ nhất và thứ hai hàm trên. Phương pháp: Nghiên cứu cắt ngang phân tích, mẫu nghiên cứu gồm 45 răng cối lớn hàm trên (Carabelli độ 0 là 16 răng, dạng hố rãnh là 16 răng, dạng núm là 13 răng). Chu vi thân răng được xác định bằng cách vẽ một đường cong vòng theo đường viền của răng dựa trên ảnh chựp kĩ thuật số, đường viền được vẽ và đo đạc bằng phần mềm Autocad 2007 trên máy vi tính. Kết quả: Chu vi thân răng ở các hạng biểu hiện đặc điểm Carabelli là tương đối khác nhiau ở M1 lần lượt là hang $0(38,5 \pm 0,89)$ hang $1(39,6 \pm 1,32)$ hạng $2(40,7 \pm$ $1,4)$; ở M2 lần lượt là hạng $0(38,4 \pm 0,89)$ hạng 1 